\title{
PENGARUH KECERDASAN INTELEKTUAL TERHADAP KINERJA GURU DALAM MENGAJAR DI SMAN 5 KEDIRI
}

\author{
Enni Sustiyatik
}

Kadiri University

J1. Selomangleng No.1, Indonesia

enny_sustiyatik@unik-kediri.ac.id

\begin{abstract}
Logically the theacher has manner to improve his performance in teaching students at school.This will affect if the use of intellectual intelligence is used in teaching. The purpose of this study was to determine the effect of intellectual intelligence on teacher performance at SMAN 5 Kediri.

The use of analysis in this study is a logistic regression test by taking the results of the final phase likehood ratio test andthen Wald test and the result of the significant value to get a reference with the logit category do not agree, less agree and agree from the dominant value category strongly agree.

The results obtained are significant variables, the variables are $X_{1}, X_{3}, X_{4}, X_{7}, X_{8}$, $X_{9}, X_{10}, X_{11}, X_{12}, X_{14}$ due to use of a $95 \%$ confidence level. Then, the variable was tested Wald get the results of the category disagree because the current conditions that are easy to change but are still suitable for research use with the results of the suitability test that has meaning if the Sig. > alpha (p-value > 0.0050) it is that the model used is in accordance with variable data and can be used.
\end{abstract}

\section{Keywords: Intellectual Intelligence, Logistic Regression Test, Wald Test}

\section{PENDAHULUAN}

Berkaitan bidang pengajaran ilmu di sekolah, seorang guru tidak lepas dari perannya selain memberikan materi pelajaran terkait prestasi akademik disekolah, juga dapat berperan sebagai pemberi motivasi dalam terlaksananya proses belajar mengajar. Oleh karena itu, seorang guru perlu bersikap adil, objektif, memberi motivasi, selalu menerima kritik saran dari muridnya. Maka, terkait hal - hal tersebut akan mengerucut pada dimensi intelektual seorang guru dalam perannya ketika mengajar dikelas. Peran intelektual inilah yang memungkinkan mampu menarik minat murid untuk menggali potensi dalam belajar disekolah baik dalam bidang akademik dan bidang non akademik. Didalam bidang akademik berkaitan dengan mata pelajaran yang sedang ditempuh oleh murid, sedangkan untuk bidang non akademik akan berkaitan dengan daya kembang pola pikir kreatif yang arahnya bisa di asah melalui mengikuti kegiatan 
ekstrakulikuler serta bimbingan maupun kursus dengan bidang yang disukai oleh murid tersebut. Dari situlah dapat diambil fokus kegiatan guru yang seharusnya dilakukan demi menunjang perkembangan pendidikan dan meciptakan karakter murid agar mampu mengembangkan kondisi yang saat ini banyak menimbulkan masalah- masalah kecil terkait dengan murid yang susah diatur, kemudian murid bandel, murid yang punya bakat tapi tidak memiliki tempat untuk melakukan pengembangan bakat, selanjutnya murid perlu diberi dukungan dalam melakukan pengembangan potensinya (Patnani, 2013).

Peran utama seoarang guru yaitu memahami karakter- karakter tiap muridnya terutama yang dibimbingnya dalam mata pelajaran maupun kegiatan non akademik disekolah. Aktivitas memahami karakter murid dapat ditunjukkan dengan dimensi intelektual (Wahyudi, 2011). Dalam dimensi intelektual inilah, guru harus mampu meberikan proses belajar, memberikan pengambilan keputusan, memberikan solusi terhadap masalah yang dihadapi murid tersebut. Dalam penelitian ini, akan memfokuskan keadaan pada kinerja guru dalam memberikan pengajaran disekolah baik dalam kegiatan akademik dan non akademik. Berdasarkan ilustrasi diatas, diambil judul yaitu "Pengaruh Kecerdasan Intelektual Terhadap Kinerja Guru Di SMAN 5 Kediri”.

Berdasarkan latar belakang diatas, maka perumusan masalahnya yaitu bagaimana pengaruh kecerdasan intelektual terhadap kinerja guru di SMAN 5 Kediri.

Berdasarkan perumusan masalah diatas, maka tujuan penelitian yaitu untuk mengetahui pengaruh kecerdasan intelektual terhadap kinerja guru di SMAN 5 Kediri.

\section{KERANGKA TEORITIS}

\section{Kecerdasan Intelektual}

$$
\text { Menurut Boehm (2011), }
$$
kecerdasan intelektual juga dapat diartikan sebagai kemampuan kognitif yang dimiliki organisme untuk menyesuaikan diri secara efektif pada lingkungan yang kompleks dan selalu berubah serta dipengaruhi oleh faktor genetic.

Kualitas setiap individu mampu dibedakan dengan kemampuan yang dimilikinya. Berdasarkan hal tersebut akan dilakukan tes yang berkaitan dengan kecerdasannya. Salah satu kecerdasan yang dilakukan penelitian 
yaitu kecerdasan intelektual. Kecerdasan intelektual inilah yang mampu digunakan untuk berpikir kognitif dalam adaptasi diri secara efektif pada lilngkungan yang kompleks serta lingkungan yang saat ini terjadi yaitu kondisi yang tidak pasti karena ada faktor- faktor lingkungan. Indikatir yang penting dimiliki oleh kecerdasan intelektual yaitu menyangkut masalah cara dan upaya untuk melakukan keeratan antara kecerdasan dengan kemauan yang digunakan untuk mencapai prestasi kerja (Rahmasari, 2012).

Kemampuan figur berkaitan dengan cara pemahaman dan cara menalar secara logis dalam bidang bahasa. Karena bidang bahasa berkaitan dengan perasaan dan jika ada bahasa yang tidak sesuai dengan individu, maka respon tubuh akan berargumen bahwa bahasa didalam kata tersebut tidak mampu diterima oleh nalar dan perasaan. Kemampuan verbal akan berkaitan dengan pemahaman dan penalaran dalam bidang bahasa, yang dapat diartikan didalam kemampuan verbal individu mampu mengucap kata secara jelas dan mampu memberikan umpan balik terhadap perintah atau kalimat yang didengarnya dari cara berkomunikasi (Santika Putra \& Latrini, 2016).

Pemahaman dan penalaran dalam bidang numerik merupakan pengetahuan individu didalam bidang perhitungan angka. Maka, didalam perhitungan angka, individu akan berpikir setiap kali melakukan proses perhitungan untuk menghasilkan jawaban yang benar atas aktivitas perhitungan angka yang sedang dikerjakan. Didalam kecerdasan intelektual memiliki lima dimensi sebagai berikut (Anis Choiriah, 2013) :

1. Kognisi yaitu tentang operasi yang menjadi pokok dari adanya intelektual dalam suasana proses kegiatan belajar. Dalam kegiatan belajar tidak harus dikaitkan dengan belajar akademik disekolah, melainkan juga dapat dikaitkan dengan belajar non akademik disekolah.

2. Melakukan aktivitas mengingat terhadap kegiatan yang sudah dilakukan. Hal ini berguna untuk membuka kembali memori ingatan yang sudah merekam berbagai aktivitas kegiatan pada waktu yang sudah berlalu.

3. Melakukan cara berpikir divirgen yang mencangkup cara pengasahan bakat dan minat agar individu mampu 
berpikir kreatif dan melakukan sesuatu yang saat itu memberikan nilai positif.

4. Melakukan cara berpikir konvergen yaitu melakukan cara untuk menghasilkan informasi yang sudah ada dan memberikan respon untuk menanggapi permasalahan yang ada.

5. Berdasarkan lima dimensi tersebut, maka keenam yaitu evaluasi yang disebut sebagai cara menghasilkan keputusan atau mencari informasiinformasi dari kegiatan yang dihasilkan agar terjadi pengambilan keputusan yang tidak merugikan individu maupun orang lain.

Kecerdasan intelektual yang ada pada individu merupakan pemberian Tuhan Yang Maha Kuasa sejak didalam kandungan. Pada kecerdasan inilah, individu akan memiliki sikap dan sikap yang berbeda- beda, baik dalam sikap cara berpikir kreatif maupun berpikir analitis. Kecerdasan intelektual inilah akan berkaitan dengan kinerja dari guru dalam memberikan materi - materi pembelajaran disekolah untuk mendidik karakter murid agar memiliki cara pola pikir yang positif dan mampu melakukan aktivitas yang kreatif (Sina \& Noya, 2009).
Seorang guru akan memiliki cara cara yang efektif untuk memberikan pengajaran kepada muridnya, maka disinilaj kecerdasan intelektual seorang guru digunakan dan harus diterapkan untuk permasalahan pendidikan dari segi akademik dan non akademik (Tjun, Setiawan, \& Setiana, 2009).

\section{Kinerja Guru}

Capaian dari kegiatan yang sudah dilakukan dan menghasilkan evaluasi akan digunakan untuk tinjauan kegiatan dimasa mendatang. Dalam capaian tersebut, dapat di fungsikan sebagai interaksi yang tergabung dari faktor kemampuan individu dan motivasi yang diberikan oleh individu dalam rangka merencakan perbaikan aktivitas. Adanya motivasi dan kemampuan yang dihasilkan oleh individu akan mampu menyusun target yang akan dicapai selain dari evaluasi ditiap periode kerja, tapi capaian yang utama yaitu hasil proses dari aktivitas setiap periode yang digunakan untuk mengetahui seberapa besar kinerja individu dalam melakukan aktivitasnya sesuai aturam yang telah diberikan (Susanto, 2013).

Menurut (Karweti, 2010) dalam kinerja individu yang sudah dicapai, akan dilakukan evaluasi untuk memberi perbaikan di aktivitas tersebut. 
Meskipun tiap periode akan dilakukan perbaikan, tidak menutup kemungkinan jika kegiatan yang dilakukan akan menurun kinerjanya dikarenakan sudah tidak ada ketakutan dalam aturan- aturan yang diberikan. Sanksi dalam hal ini, perlu diterapkan untuk menghindari penurunan kinerja individu.

Kinerja individu sangat luas sekali objeknya menurut (Septiana, Ngadiman, \& Ivada, 2013), maka dalam konteks penelitian ini akan diambil objek yaitu guru sebagai sasaran yang akan dilakukan evaluasi kinerjanya. Kinerja yang dilukan guru dalam bidang pendidikan terkait disekolah, yaitu kinerja dalam mengajar. Didalam mengajar, murid yang diajarnya belum tentu memahami materi yang telah diberikan, dikarenakan ada faktor- faktor yang belum mendukung. Ada kriteria yang dapat digunakan untuk mengukur kinerja dari guru dibidang pendidikan dalam proses belajar mengajar sebagai berikut (Wibowo, 2013):

1. Kualitas. Kualitas akan mengarah pada hasil yang dicapai oleh individu yang mendekati sempurna sesuai dengan harapan instansi. Maka, jika kualitas yang dicapai individu sesuai harapan, dapat dikatakan individu tersebut sudah melakukan kewajibannya untuk taat pada aturan yang diberikan oleh instansi atau bahkan individu memiliki pemikiran yang mampu memberikan perbaikan bahkan pengembangan instansi tempat kerjanya.

2. Kuantitas. Kuantitas akan berkaitan dengan jumlah aktivitas yang dikerjakan oleh individu didalam lingkup instansi sesuai aturan dari instansi tersebut. Jumlah kegiatan yang dihasilkan jika sudah sesuai harapan instansi, maka individu dikatakan sudah berperan sesui kinerja yang diberikan.

3. Ketepatan waktu. Dalam ketepatan waktu, akan berkaitan dengan berapa lama aktivitas yang dikerjakan oleh individu tersebut. Lama tidaknya aktivitas yang dilakukan akan memberi pengaruh terhadap kinerjanya di instansi. Jika individu mampu mengerjakan aktivitasnya sesuai dibawah waktu maksimal akan memberikan nilai plus serta individu akan dijadikan contoh teladan bagi individu yang lain.

4. Efektifitas. Berkaitan dengan efektifitas akan berfokus pada tingkat pengetahuan dari sumber daya manusia yang digunakan pada instansi tersebut. Didalam efektifitas, 
berkaitan dengan seberapa besar untung yang dapat diambil oleh individu selama melakukan proses aktivitasnya. Dalam hal ini, jika individu mampu melakukan kegiatan lebih cepat dari waktu normal yang diberikan instansi, maka instansi akan memberikan keuntungan yang lebih.

5. Kemandirian. Kegiatan didalam aktivitas kerja, berkaitan dengan kemandirian dari individu. Jika dalam bekerja, tidak ada instruksi bekerja kelompok, alangkah baiknya individu tidak melakukan kegiatan berkelompok untuk menghindari teguran dari instansi.

6. Komitmen. Komitmen yang diberikan oleh individu, akan berfungsi sebagai seberapa besar tanggung jawab yang diberikan kepada individu dan seberapa besar individu mampu mengerjakan dan menjaga amanat komitmen agar tetap melakukan pekerjaan sesuai anjuran instansi.

Kinerja individu menurut (Ramli \& Jalinus, 2013), hal - hal yang dilihat dari segi kuantitas adalah jangka waktu output yang dihasilakan oleh individu, kemudian kualitas output yang dicapai oleh individu, kemudian kuantitas output yang dihasilkan dalam setiap kegiatan serta ketepatan kehadiran ditempat kerja dan perlunya sikap yang kooperatif disetiap aktivitasnya.

Cara pemberian nilai dari kinerja individu, akan memiliki tujuan pertama yaitu pemberian penghargaan kepada individu sebagai langkah agar individu akan mengembangkan kinerjanya lebih baik lagi, kemudian untuk penilaian kinerja yang kedua yaitu pemberian informasi terkait waktu ketepatan dalam pemberin gaji, melakukan tinjauan perilaku yang dapat digunakan untuk melakukan pengembangan karir individu agar dapat dicapai peluang yang baik dalam memahami karir dimasa mendatang.

\section{METODE PENELITIAN}

\section{Lokasi dan Tempat Penelitian}

Lokasi penelitian adalah tempat yang digunakan dalam melakukan penelitian untuk memperoleh data yang diinginkan. Pada tempat penelitian ini penulis memilih di SMA N 5 Kediri.

\section{Instrumen Penelitian}

Adapun instrumen penelitian yang digunakan dalam penelitian ini adalah sebagai berikut:

1. Melakukan wawancara atau mengadakan komunikasi langsung dengan bapak/ ibu guru di SMA N 5 
Kediri tentang kecerdasan intelektual guru dalam mengajar muridnya.

2. Melakukan observasi penelitian dilakukan dengan pengisian kuisoner kepada bapak/ ibu guru sejumlah 50 responden.

3. Melakukan pengolahan data kuisioner menggunakan Microsoft Excel 2016 dan menggunakan software IBM SPSS Statistic versi 23.

4. Melakukan analisis pada data- data yang sudah dimasukkan ke Microsoft Excel 2016 dan melakukan analisis dengan metode pendeskripsian dengan tujuan untuk mengetahui seberapa besar pengaruh yang timbul dengan adanya pengaruh kecerdasan intelektual yang digunakan guru saat mengajar muridnya dengan melihat pertnyaan sesuai kuisioner dari pengisian kuisioner tersebut kemudian menggunakan analyze uji regresi logistik multinomial yang berfungsi untuk melakukan analisis dampak yang ditimbulkan dari pengaruh kecerdasan intelektual yang digunakan guru saat mengajar muridnya (Safi'i, Sutriyono, \& Handoko, 2015).

5. Dari kuisioner yang akan diisi oleh peserta didik memiliki dimensi intelektual sebanyak 15 pertanyaan dengan variabel bebas yaitu kinerja guru dalam mengajar dan variabel terikat yaitu pengaruh kecerdasan intelektual menggunkaan kategori tidak setuju dengan nilai 1, kurang setuju dengan nilai 2 , setuju dengan nilai 3 dan sangat setuju dengan nilai 4.

\section{HASIL PENELITIAN \\ Uji Regresi Logistik}

Berikut ini merupakan hasil dari perhitungan uji regresi logistik multinomial yang akan digunakan untuk mengetahui pengaruh kecerdasan intelektual terhadap kinerja guru di SMAN 5 Kediri dengan melakukan uji likehood-ratio test tahap pertama. Dari uji likehood-test tahap pertama dihasilkan data yang memiliki variabel berjumlah 15 variabel dilihat pada tabel 1. Dari 15 varibel tersebut, memiliki kondisi signifikan jika nilai Sig. yang diperoleh p-value < alpha ( $\mathrm{p}$-value < 0.0050), jika hasil nilai Sig. $>0.0050$ maka dikatakan variabel tersebut tidak signifikan. Dari tabel 1 hasil likehood ratio test didapatkan variabel yang tidak signifikan yaitu variabel: $\mathrm{X}_{1}, \mathrm{X}_{5}, \mathrm{X}_{6}, \mathrm{X}_{13}$ dan $X_{15}$. Berdasarkan hasil tersebut, akan dilakukan hasil likehood- ratio test kedua yang diuji regresi logistik yaitu variabel yang memiliki nilai Sig. < 0.0050. Maka, 
hasil uji likehood-ratio kedua didapat hasil bahwa variabel yang signifikan yaitu varibel $\mathrm{X}_{1}, \mathrm{X}_{3}, \mathrm{X}_{4}, \mathrm{X}_{7}, \mathrm{X}_{8}, \mathrm{X}_{9}, \mathrm{X}_{10}$, $\mathrm{X}_{11}, \mathrm{X}_{12}$ dan $\mathrm{X}_{14}$ dikarenakan penggunaan dari tingkat kepercayaan 95\% maka didapat hasil signifikan ada ditabel 2. Tujuan dari uji likehood-ratio test yaitu untuk mengetahui apak ada pengaruh antara variabel dependen terhadap variabel independen. Uji likehood kedua ini merupakan hasil akhir dari uji likehood ratio test dilihat pada tabel 2 .

Tabel 1. Hasil likehood- ratio test tahap pertama

\begin{tabular}{ccccc}
\hline Variabel & Likehood of reduce model & df & Sig. & Keterangan \\
\hline Intercept & 6.930 & 3 & 0.000 & Signifikan \\
$\mathrm{X}_{1}$ & 6.930 & 3 & 0.000 & Signifikan \\
$\mathrm{X}_{2}$ & 13.360 & 3 & 0.092 & Tidak Signifikan \\
$\mathrm{X}_{3}$ & 6.930 & 3 & 0.000 & Signifikan \\
$\mathrm{X}_{4}$ & 6.930 & 3 & 0.000 & Signifikan \\
$\mathrm{X}_{5}$ & 13.617 & 3 & 0.083 & Tidak Signifikan \\
$\mathrm{X}_{6}$ & 6.932 & 3 & 1.000 & Tidak Signifikan \\
$\mathrm{X}_{7}$ & 6.930 & 3 & 0.000 & Signifikan \\
$\mathrm{X}_{8}$ & 6.930 & 3 & 0.000 & Signifikan \\
$\mathrm{X}_{9}$ & 6.930 & 3 & 0.000 & Signifikan \\
$\mathrm{X}_{10}$ & 6.930 & 3 & 0.000 & Signifikan \\
$\mathrm{X}_{11}$ & 6.931 & 3 & 0.000 & Signifikan \\
$\mathrm{X}_{12}$ & 26.738 & 3 & 0.000 & Signifikan \\
$\mathrm{X}_{13}$ & 7.800 & 3 & 0.833 & Tidak Signifikan \\
$\mathrm{X}_{14}$ & 27.777 & 3 & 0.000 & Signifikan \\
$\mathrm{X}_{15}$ & 12.844 & 3 & 0.116 & Tidak Signifikan \\
\hline
\end{tabular}

Sumber: data diolah, 2019

Berdasarkan tabel 2 yaitu hasil uji likehood ratio test tahap akhir yang merupakan variabel- variabel kecerdasan intelektual yang berpengaruh terhadap kinerja guru dalam mengajar murid di SMAN 5 Kediri. Berdasarkan nilai Sig, yang didapatkan, variabel - variabel tersebut sudah memiliki hasil nilai Sig. < alpha (P-value < 0.0050). Maka, diambil keputusan dari hasil tersebut bahwa hasil likehood ratio test dapat dilanjutkan ke dalam perhitungan uji estimasi paramater

Tabel 2. Hasil likehood- ratio test tahap akhir

\begin{tabular}{ccccc}
\hline Variabel & $\begin{array}{c}\text { Likehood of reduce } \\
\text { model }\end{array}$ & df & Sig. & Keterangan \\
\hline Intercept & 8.277 & 3 & 0.000 & Signifikan \\
$\mathrm{X}_{1}$ & 20.325 & 3 & 0.007 & Signifikan \\
$\mathrm{X}_{3}$ & 24.467 & 3 & 0.001 & Signifikan \\
\hline
\end{tabular}




\begin{tabular}{lclll}
\hline $\mathrm{X}_{4}$ & 16.296 & 3 & 0.046 & Signifikan \\
$\mathrm{X}_{7}$ & 28.002 & 3 & 0.000 & Signifikan \\
$\mathrm{X}_{8}$ & 8.277 & 3 & 0.000 & Signifikan \\
$\mathrm{X}_{9}$ & 8.278 & 3 & 0.000 & Signifikan \\
$\mathrm{X}_{10}$ & 17.514 & 3 & 0.026 & Signifikan \\
$\mathrm{X}_{11}$ & 8.277 & 3 & 0.000 & Signifikan \\
$\mathrm{X}_{12}$ & 21.397 & 3 & 0.004 & Signifikan \\
$\mathrm{X}_{14}$ & 21.301 & 3 & 0.005 & Signifikan \\
\hline
\end{tabular}

Sumber: data diolah, 2019

Berdasarkan tabel 3 hasil uji Variabel - variabel pada uji likehood parameter dibawah ini berkaitan dengan ratio test mampu memberi pengaruh pengambilan keputusan bahwa apakah terhadap kinerja guru dalam mengajar. benar

Tabel 3. Hasil Uji Estimasi Parameter

\begin{tabular}{|c|c|c|c|c|c|}
\hline Parameter & Variabel & B & Uji Wald & df & Sig. \\
\hline \multirow[t]{11}{*}{ Tidak Setuju } & Intercept & -79.028 & 0.000 & 1 & 0.993 \\
\hline & $\mathrm{X}_{1}$ & -26.319 & 0.016 & 1 & 0.901 \\
\hline & $X_{3}$ & -28.603 & 0.001 & 1 & 0.981 \\
\hline & $\mathrm{X}_{4}$ & -35.795 & 0.001 & 1 & 0.981 \\
\hline & $\mathrm{X}_{7}$ & 26.589 & 0.021 & 1 & 0.886 \\
\hline & $\mathrm{X}_{8}$ & 15.550 & 0.001 & 1 & 0.977 \\
\hline & $\mathrm{X}_{9}$ & -6.599 & 0.000 & 1 & 0.997 \\
\hline & $\mathrm{X}_{10}$ & -33.163 & 0.000 & 1 & 0.984 \\
\hline & $\mathrm{X}_{11}$ & 11.438 & 0.000 & 1 & 0.990 \\
\hline & $X_{12}$ & 71.076 & 0.000 & 1 & 0.000 \\
\hline & $\mathrm{X}_{14}$ & 46.981 & 0.019 & 1 & 0.890 \\
\hline \multirow[t]{11}{*}{ Kurang Setuju } & Intercept & -89.571 & 0.000 & 1 & 0.995 \\
\hline & $\mathrm{X}_{1}$ & -9.384 & 0.000 & 1 & 0.993 \\
\hline & $\mathrm{X}_{3}$ & -24.588 & 0.000 & 1 & 0.985 \\
\hline & $\mathrm{X}_{4}$ & -22.749 & 0.000 & 1 & 0.987 \\
\hline & $\mathrm{X}_{7}$ & 26.328 & 0.001 & 1 & 0.979 \\
\hline & $\mathrm{X}_{8}$ & 26.367 & 0.001 & 1 & 0.980 \\
\hline & $\mathrm{X}_{9}$ & -18.948 & 0.000 & 1 & 0.992 \\
\hline & $\mathrm{X}_{10}$ & -24.349 & 0.000 & 1 & 0.986 \\
\hline & $\mathrm{X}_{11}$ & 3.969 & 0.000 & 1 & 0.998 \\
\hline & $\mathrm{X}_{12}$ & 55.559 & 0.001 & 1 & 0.981 \\
\hline & $\mathrm{X}_{14}$ & 21.585 & 0.000 & 1 & 0.988 \\
\hline \multirow[t]{7}{*}{ Setuju } & Intercept & -42.824 & 0.001 & 1 & 0.972 \\
\hline & $\mathrm{X}_{1}$ & -22.233 & 0.024 & 1 & 0.876 \\
\hline & $X_{3}$ & -40.417 & 0.032 & 1 & 0.858 \\
\hline & $X_{4}$ & -37.541 & 0.026 & 1 & 0.871 \\
\hline & $\mathrm{X}_{7}$ & 27.975 & 0.023 & 1 & 0.880 \\
\hline & $\mathrm{X}_{8}$ & 19.192 & 0.005 & 1 & 0.941 \\
\hline & $X_{9}$ & -12.035 & 0.003 & 1 & 0.959 \\
\hline
\end{tabular}




\begin{tabular}{ccccc}
\hline $\mathrm{X}_{10}$ & -34.078 & 0.018 & 1 & 0.893 \\
$\mathrm{X}_{11}$ & 6.158 & 0.004 & 1 & 0.952 \\
$\mathrm{X}_{12}$ & 80.874 & 0.027 & 1 & 0.871 \\
$\mathrm{X}_{14}$ & 41.545 & 0.029 & 1 & 0.866 \\
\hline
\end{tabular}

Sumber: data diolah, 2019

Maka, analisis fungsi parameter pada tabel 3 hasil uji estimasi parameter didapatkan tiga fungsi model logistik multinomial dengan logit sebagai berikut:

1. Logit 1, ketidak setujuan pendapat dari kecerdasan intelektual guru mampu memberi pengaruh dalam mengajar murid dengan kesangat setujuan pendapat dari kecerdasan intelektual guru mampu memberi pengaruh dalam mengajar murid dengan acuan :

Logit $1=-79.028-26.319 \times 1-$ $28.603 \times 3-35.795 \times 4+26.589 \times 7+$ $15.550 \times 8-6.599_{X 9}-33.163_{X 10}+$ $11.438 \mathrm{X} 11+71.076_{\mathrm{X} 12}+46.981_{\mathrm{X} 14}$

2. Logit 2, kekurang setujuan pendapat dari kecerdasan intelektual guru mampu memberi pengaruh dalam mengajar murid dengan kesangat setujuan pendapat dari kecerdasan intelektual guru mampu memberi pengaruh dalam mengajar murid dengan acuan : Logit $2=-89.571-$ $9.384 \mathrm{x} 1-24.588 \mathrm{x} 3-22.749 \mathrm{X}_{4}+$ $26.328 \times 7+26.367 \mathrm{X8}-18.948 \mathrm{X} 9-$
$24.349 \mathrm{X} 10+3.969 \mathrm{X} 11+55.5599_{\mathrm{X} 12}+$ $21.585 \times 14$

3. Logit 1, kesetujuan pendapat dari kecerdasan intelektual guru mampu memberi pengaruh dalam mengajar murid dengan kesangat setujuan pendapat dari kecerdasan intelektual guru mampu memberi pengaruh dalam mengajar murid dengan acuan

Logit $3=-42.824-22.233 \times 1-$ $40.417 \mathrm{X} 3-37.541_{\mathrm{X} 4}+27.975 \mathrm{X} 7+$ $19.192 \times 8-12.035 \times 9-34.078 \times 10+$ $6.158 \times 11+80.874 \times 12+41.545_{\mathrm{X} 14}$

Berdasarkan pengambilan keputusan pada tabel 3 di uji Wald dan diringkas menggunakan acuan logit 1, logit 2 dan logit 3 maka dapat diketahui pada variabel: $X_{1}$ yaitu guru mampu membangkitkan suasana belajar bagi murid dengan nilai 0.016 dengan Sig. sebesar 0.993 pada kategori ketidak setujuan, kategori kurang setujuan memiliki nilai 0.000 dengan nilai Sig. sebesar 0.993 dan kategori setuju dengan nilai 0.024 dan nilai Sig. sebesar 0.876 . Dalam hal ini, pemilihan kategori ketidak setujuan dan kurang setuju 
terhadap guru mampu membangkitkan suasana belajar bagi murid masih mendominasi karena setiap guru mungkin belum mampu membangkitkan suasana belajar sesuai harapan murid disekolah. Variabel $X_{3}$ yaitu guru mampu menyisipkan kondisi terkini ke dalam materi belajar dengan nilai sebesar 0.001 dengan nilai sig. sebesar 0.901 kategori ketidak setujuan, kategori kurang setuju dengan nilai 0.000 dan nilai Sig. sebesar 0.993 dan kategori setuju dengan nilai sebesar 0.032 dan nilai Sig. sebesar 0.876. Di era saat ini, setiap guru harus mampu menyisipkan isu terkini disetiap mata pelajaran, hal ini berfungsi untuk membuka pengetahuan murid agar tidak monoton dalam menerima materi pembelajaran karena hasil uji wald lebih dominan kurang setuju jika guru menyisipkan kondisi terkini, mungkin penyebab kurang setuju dikarenakan saat ini informasin yang tersebar dimedia kurang disaring pada akhirnya rawan menerima berita yang belum tentu faktanya. Variabel X4 yaitu guru mampu memotivasi murid untuk menumbuhkan bakat dengan nilai sebesar 0.001 dengan nilai Sig. sebesar 0.981 dalam kategori ketidak setujuan, kategori kurang setuju dengan nilai sebesar 0.000 dan sig. sebesar 0.987 dan kategori setuju dengan nilai sebesar 0.026 dan nilai sig. sebesar 0.871 . Variabel ini berkaitan dengan cara memotivasi murid agar tahu bakat yang dimilikinya, dalam hal ini nilai tertinggi berada pada kategori kurang setuju, disebabkan setiap guru masih belum memiliki sikap psikologis dikarenakan bidang ajar disekolah tidak memegang/ tidak mengajar psikologi. Variabel $\mathrm{X}_{7}$ yaitu guru mendukung secara materi dan finansial pada murid yang ingin mengasah bakatnya dengan nilai 0.021 dan nilai sig. sebesar 0.886 dalam kategori ketidak setujuan, kategori kurang setuju dengan nilai 0.001 dan nilai Sig. sebesar 0.979 dan kategori setuju dengan nilai 0.023 dan nilai sig. 0.880. Dari nilai tertinggi didapat dari kategori kurang setuju, disebabkan setiap guru belum tentu memiliki finansial pribadi yang digunakan untuk membiayai muridnya, dikarenakan lebih baik mementingkan keluarga dan anak terlebih dahulu. Variabel $\mathrm{X}_{8}$ yaitu guru selalu melakukan umpan balik 20 menit sebelum jam pelajaran selesai dengan nilai 0.001 dan sig. sebesar 0.977 dalam kategori ketidak setujuan, untuk kategori kurang setuju dengan nilai sebesar 0.001 dan nilai sig. sebesar 0.980 dan kategori setuju dengan nilai sebesar 0.005 dan sig. 
sebesar 0.941. Di kategori kurang setuju lebih dominan disebabkan, guru ketika dikelas mayoritas masih mementingkan materi yang harus diselesaikan sesuai modulnya, untuk umpan balik mayoritas murid ketika ditanya hanya diam, itu yang menjadi penyebab variabel $\mathrm{X}_{8}$ masih belum relevan di lingkup kecerdasan intelektual di SMAN X Kediri. Variabel $\mathrm{X}_{9}$ yaitu guru menyediakan waktu diskusi diluar jam pelajaran pada murid- murid dengan nilai sebesar 0.000 dan sig. sebesar 0.997 dalam kategori ketidak setujuan, dalam kategori kurang setuju dengan nilai sebesar 0.000 dan nilai sig. sebesar 0.992 dan kategori setuju dengan nilai 0.003 dan nilai sig. sebesar 0.959. Dominan tertinggi berada pada kategor tidak setuju, disebabkan guru setelah mengajar mayoritas akan lebih mempentingkan kegiatan dirumah terlebih dahulu, jika sore hari ada waktu kosong murid bisa menghubungi kembali untuk diskusi. Variabel $\mathrm{X}_{10}$ yaitu guru sering berkomunikasi dan akrab kepada murid - murid dengan nilai sebesar 0.000 dan nilai sig. sebesar 0.984 dalam kategori ketidak setujuan, kategori kurang setuju dengan nilai 0.000 dan nilai sig. sebesar 0.986 dan kategori setuju dengan nilai sebesar 0.018 dan nilai sig. sebesar
0.893. Maka, dominasi tertinggi berada pada kategori kurang setuju disebabkan guru biasanya lebih memiliki kesibukan setelah mengajar dikarenakan saat waktu - waktu tertentu tidak bisa diajak berkomunikasi secara lama. Variabel $\mathrm{X}_{11}$ yaitu guru menyediakan konseling kepada murid - murid terhadap keluh kesah disekolah maupun diluar sekolah dengan nilai 0.000 dan nilai sig. sebesar 0.990 dalam kategori ketidaksetujuan, kategori kurang setuju dengan nilia sebesar 0.000 dan nilai sig. sebesar 0.998 dan kategori setuju dengan nilai 0.004 dan nilai sig. sebesar 0.952. Kategori kurang setuju lebih dominan dikarenakan setiap guru belum tentu memahami bidang konseling dikarenakan tidak mengajar materi tersebut. Variabel $\mathrm{X}_{12}$ yaitu guru selalu mengambil keputusan pemberian tugas secara musyarah kepada murid dengan nilai sebesar 0.000 dan nilai sig. sebesar 0.000 dalam kategori ketidak setujuan, untuk kategori kurang setuju dengan nilai sebesar 0.001 dan nilai sig. sebesar 0.981 dan kategori setuju dengan nilai sebesar 0.027 dan nilai sig. sebesar 0.871. Kategori setuju akan memberi pengaruh lebih besar dikarenakan guru dalam memberikan tugas lebih baik menyesuaikan dengan karakter 
muridnya agar tugas mampu diselesaikan dengan maksimal. Variabel X14 yaitu guru lebih suka dengan murid yang memiliki rasa ingin tahu terhadap materi pelajaran dengan nilai sebesar 0.019 dan nilai sig. sebesar 0.890 dalam kategori ketidak setujuan, kategori kurang

setuju dengan nilai sebesar 0.000 dan nilai sig. sebesar 0.988 dan kategori setuju dengan nilai sebesar 0.029 dan nilai sebesar 0.866 .

Di kategori tidak setuju lebih dominan, karena belum tentu murud yang memiliki rasa ingin tahu akan lebih memperhatikan gurunya ketika mengajar, ini juga terkadang murid bercanda dalam memberi pertanyaan untuk dijawab oleh gurunya.

Tabel 4. Goodness of Fit

\begin{tabular}{cccc}
\hline Metode & Chi - Square & Df & Sig. \\
\hline Pearson & 0.000 & 63 & 1.000 \\
Deviance & 0.001 & 63 & 1.000
\end{tabular}

Sumber: data diolah, 2019

Tabel 4 merupakan uji kesesuaian yang memiliki arti jiak nilai Sig. > alpha (p-value > 0.0050) dikatakan model yang digunakan sudah sesuai dengan data variabel dan dapat digunakan.

\section{KESIMPULAN}

Berdasarkan penelitian yang dilakukan pada SMAN X Kediri didapatkan hasil dari pengaruh kecerdasan intelektual terhadap kinerja guru dalam mengajar masih dalam kategori jawaban kurang setuju. Jawaban tersebut didapatkan dari variabelvariabel yang sudah dilakukan uji regresi logistik dengan hasil dari uji Wald dan nilai Sig. Maka, dalam rangka memberikan pengaruh kecerdasan intelektual tersebut didalam mengajar guru harus selalu membangkitkan suasana belajar didalam kelas agar timbul rasa ingin tahu murid terhadap kondisi terkini dilingkungan luar. Berdasarkan kondisi terkini, dapat dilakukan penggalian karakter murid akan hal tentang penumbuhan bakat, karena bakat akan tumbuh dan berkembang jika ada motivasi dan dalam hal finansial mungkin belum mampu dilakukan untuk mengembangan bakat. Karena finansial yang dimaksud diambil dari guru masing- masing. Tentang rasa ingin tahu murid, guru harus meluangkan waktu diluar jam untuk menerima murid yang ingin berdiskusi masalah pelajaran maupun diluar materi pelajaran, hal ini 
berfungsi untuk memberi rasa akrab antara guru dengan murid untuk mengetahui bagaimana karakter muridmurid yang dimbimbing untuk mengetahui kemampuan dalam menyelesaikan tugas yang telah diberikan.

\section{DAFTAR PUSTAKA}

Anis Choiriah. 2013. Pengaruh kecerdasan emosional, kecerdasan intelektual, kecerdasan spiritual, dan etika profesi terhadap kinerja auditor dalam akuntan publik. Jurnal Akuntansi, 1(1), 3-22. Retrieved from http://ejournal.unp.ac.id/students/i ndex.php/akt/article/view/107/95

Boehm, M., 2011. Factor Structure of the Wechsler Intelligence Scale for Children-Fourth Edition among Students with Attention Deficit Hyperactivity Disorder. Thesis. Arizona State University

Karweti, E. 2010. Pengaruh Kemampuan Manajerial Kepala Sekolah Dan Faktor Yang Mempengaruhi Motivasi Kerja Terhadap Kinerja Guru SLB Di Kabupaten Subang. Journal Penelitian Pendidikan.

Patnani, M. 2013. Upaya Meningkatkan Kemampuan Problem Solving Pada Mahasiswa. Jurnal Psikogenesis.

Rahmasari, L. 2012. Pengaruh kecerdasan intelektual, kecerdasan emosi dan kecerdasan spiritual terhadap kinerja karyawan (The Effect of Intellectual Intelligence,
Emotional Intelligence and Spiritual Intelligence on Employee Performance). Majalah Ilmiah Informatika, 3(1), 4-5.

Ramli, R., \& Jalinus, N. 2013. Evaluasi Kinerja Guru Sekolah Menengah Kejuruan Sumatera Barat Pascasertifikasi. Jurnal Penelitian Dan Evaluasi Pendidikan. https://doi.org/10.21831/pep.v17i 1.1362

Safi'i, I., Sutriyono, \& Handoko, F. 2015. Kualitas Pelayanan di Tinjau Dari Prestasi Akademik Mahasiswa Studi Kasus Pada Universitas Kadiri. Teknologi Dan Manajemen Industri, Vol. 1.

Santika Putra, K., \& Latrini, M. 2016. Pengaruh Kecerdasan Intelektual, Kecerdasan Emosional, Kecerdasan Spiritual, Komitmen Organisasi Terhadap Kinerja Auditor. E-Jurnal Akuntansi, 17(2), 1168-1195.

Septiana, R., Ngadiman, \& Ivada, E. 2013. Pengaruh Kepemimpinan Kepala Sekolah dan Motivasi Kerja Terhadap Kinerja Guru SMP Negeri Wonosari. Jupe UNS.

Sina, P. G., \& Noya, A. 2009. Pengaruh Kecerdasaan Spirtual Terhadap Pengelolaan Keuanagan Pribadi, 11(2), 171-188

Susanto, H. 2013. Faktor-faktor yang mempengaruhi kinerja guru sekolah menengah kejuruan. Jurnal Pendidikan Vokasi, 2(2), 197-212. https://doi.org/10.21831/jpv.v2i2. $\underline{1028}$

Tjun, L., Setiawan, S., \& Setiana, S. 
2009. Pengaruh Kecerdasan Emosional Terhadap Pemahaman Akuntansi Dilihat Dari Perspektif Gender. Jurnal Akuntansi, 1(2), 101-118.
Wibowo, B. K. 2013. Pengaruh Komunikasi Internal, Motivasi Kerja, Dan Loyalitas Terhadap Kinerja Guru Sekolah Menengah Kejuruan Negeri Rumpun Bisnis Sekota Semarang. Jurnal STIE Semarang. 